\title{
The Historical "Stickiness" of Nationalism Inside Turkey's Political Field
}

\author{
EYLEM AKDENIZ* \& EMRAH GÖKER** \\ *Department of Political Science, Bilkent University, Ankara, Turkey; ${ }^{* *}$ YADA Foundation, Ankara, \\ Turkey
}

\begin{abstract}
This article revisits modern Turkish political history with a specific focus on trajectories of Turkish nationalism, from the end of the nineteenth century of the Ottoman Empire, to the forms it takes under Justice and Development Party (AKP) rule today. The discussion is theoretically embedded within a relational political-sociological framework that utilizes the "field analysis" approach developed by Pierre Bourdieu. Using this approach, this paper argues that a workable, explanatory political-sociological "surface" of analysis of Turkish politics might be "the political field." It further argues that inside this field of political forces and competing groups, there is an ordering principle that supplies the political actors with a set of beliefs concerning "what can be politicized for sustainable power." In this study, nationalism is treated as a kind of historically constituted and re-constituted "set of beliefs," or doxa in Bourdieu's terminology. The paper further explores two long-lasting "challenges" to Turkish nationalism, those of Islamist and Kurdish claims, and the recent trajectories of these two forms of politics inside the field.
\end{abstract}

History is that of struggles between nations. Each nation strives for its own existence. ... Thus, we have shouldered the mission of the Turkish Nation. There are no alien powers among us, and the Turkish people are backing us. We tell ourselves, "Only the Turk is good to the Turk," "The Turk has no friend other than the Turk" and draw our strength from our people.

$$
\text { Alparslan Türkeş }{ }^{1}
$$

\section{Introduction}

Though nationalism is not the only topic of academic interest where the legitimate mode of explanation becomes an issue within the competitive realm of rival analytical frameworks, such ordinary political differences tend to surface more sharply between scholars in the study of nationalism. Moreover, considering the fact that modern nationalisms

Correspondence Address: Eylem Akedeniz, Department of Political Science, Bilkent University, Ankara, Turkey. Email: eylemak@bilkent.edu.tr. 
originally emerged out of those social spaces which, today, are occupied by the forces of today's global hegemony, it is no surprise that there are still intellectual accounts of the progressive or civic virtues of nationalism aiming to justify the historical trajectory of Western civilizations as opposed to those trajectories doomed by ethnic rivalries. ${ }^{2}$

The study of nationalism is one area where a mechanism operates to separate and oppose the sacred and profane elements of a democratic polity. Thus, in some academic accounts, it appears very natural to demonize Serbian nationalism or Taliban fundamentalism, while applauding Swedish democracy or Turkish laicism. Meanwhile, the ambitions behind French republicanism, the problematic assumptions of German citizenship, or the ideals of NATO humanitarianism are usually taken for granted, without reflecting on the epistemological homology between what is called legitimate and illegitimate nationalisms. To illustrate this point through the consideration of the bombardment of Serbia in 1999: the invention and distribution of credibility about why the Serbian regime was evil depended on making it clear that the Western regimes involved in that war were everything that the enemy could not be. ${ }^{3}$

If the study of nationalism is overburdened with structural misrecognitions in its attempt to distinguish good and bad nationalisms, what shape might an alternative approach (whose agenda is not only scientific but also on the side of a strongly democratic politics) take? Considering that the homologies between the nationalisms of countries occupying unequal positions in today's global order can be investigated, would a study of one single case be helpful? This article does not seek another scholastic claim about the correct representation of the problem of nationalism; instead, it explores how a political-sociological approach that tries to account for the relationality between structures and individuals is possible. To achieve this, the research focuses on both past and recent dynamics of Turkish politics with a specific emphasis on the role nationalism plays as a structuring logic within the Turkish political field.

The first section of the article introduces the basic theoretical framework that helps position the proposed focus on nationalism in Turkish politics. The second section discusses the emergence of, and changes in, the political field of Turkey, all the way up to the Justice and Development Party (AKP) government. After this historical discussion, the argument moves on to the investigation of two challenges in the era following the 1980 coup which threatened nationalist hegemony-the dual (paramilitary and ethno-social) Kurdish mobilization and the heterogeneous Islamist opposition with considerable electoral power and enduring influence. It is within the scope of this paper to investigate to what extent these two challenges disrupted the structure of the political field, and how the nationalist logic has been reshaped accordingly. In conclusion, the question of the direction toward which the structure of Turkey's political field is moving is addressed with an emphasis on how the approach developed might help shed light on the future trajectory.

\section{A Relational Tool Box}

As in most fields of social scientific research, objectivist and subjectivist epistemologies are also in conflict in the study of nationalism. In the objectivist camp, 
Benedict Anderson, while introducing a valuable anthropological dimension by drawing attention to (a) the symbolic economy of nationalism, and (b) the various resources (from media to museums) that feed the "imagined constitution" of the nation, remains very much Durkheimian. ${ }^{4}$ Like the founding father of French sociology, who tended to privilege the category of "soul" (hence, "society") to prove the collective construction of social structures in people's conscience, Anderson sticks to objectivist assumptions in his search for a morphology of the imagination of the nation. People, in Anderson's account, appear only as carriers of languages or memories who fulfill the task/function of imagination.

Partha Chatterjee, the famous multi-disciplinary scholar of Subaltern Studies, supplies invaluable insights into nationalism with his distinction between the thematic and the problematic of a nationalist discourse and follows the trajectory of this discourse through the chronological trajectory of moments of departure, maneuver and arrival. ${ }^{5}$ Leaving aside the question of whether this approach is only suitable for colonized geographies, ${ }^{6}$ Chatterjee's model is problematic due to the privileged status of the position-takings of prominent nationalists, without taking their positions into account or investigating the contribution of other agents to the discourse. Thus, while the épistèmè from which nationalist discourses are born surely has a structure, Chatterjee treats this structure as if it is independent of the agents and institutions which actualize it and bring it into existence, thereby ignoring the politicalsociological connections which accompany or underwrite such logical sequences.

In the subjectivist camp, on the other hand, objective conditions rarely make a difference in the analysis of nationalism. Andrew Davison, for example, suggests a hermeneutic approach for understanding the historical claims of Kemalism about secular Republican virtues or national unity. However, he gets stuck at the level of discourse when he rejects making causal explanations of why a certain nationalist text (say, the First Congress of National Economy in Izmir, February 1923-a critical moment in the genesis of nationalist hegemony in Turkey) takes this or that assumption for granted, or what the material conditionings of the external world are, or how come agents from different backgrounds agree (or disagree) with the discourse. ${ }^{7}$ Similarly, in a study on the biological-racist discourse disseminated by the Turkish Anthropological Institute, Nazan Maksudyan invests too much in the strength and coherence of the racist essence of Turkish nationalism, without focusing on the social trajectories of the producers of that discourse, and the forms of utilization of that discourse by political actors outside the circle of nationalist social scientists. ${ }^{8}$

This paper argues that understanding the subjective meanings of a certain text should not be separated from causal explanations. To understand why a Kemalistlaicist governor has a conservative view of Kurds, or why an ultra-nationalist mayor purges Alevi employees from city services, requires more than a subjectivist dive into the deconstruction of the text. Understanding is rather

to give oneself a generic and genetic comprehension of who these individuals are, based on a (theoretical and practical) grasp of the social conditions of which they are the product: this means a grasp of the circumstances of life 
and the social mechanisms that affect the entire category to which any individual belongs ... and a grasp of the conditions, inseparably psychological and social, associated with a given position and trajectory in social space. ${ }^{9}$

Following Bourdieu's point here, it can also be argued that psychoanalytical explanations of nationalism have subjectivist limitations. Such explanations mistakenly tend to project a mode of explanation operating at the individual level (say, "fear of castration" or "mirror stage") to the institutional-structural level. While analogies between the dilemmas of personal identity formation and experiences of national identity can often be always useful, this brand of subjectivism tends to do away with the vast complexity of intermediate relations and determinations that link people to each other, and structures to people.

Homi Bhabha's (a cultural-political theorist) attempt at an ambiguous deconstruction of the relationship between the "colonizer" and "colonized" is exemplary of this kind of subjectivist theorizing on nationalism based upon problematic psychoanalytical assumptions. According to Bhabha, the "hybridity" of Third World nationalism is a result of the "closure and coherence attributed to the unconscious pole of colonial discourse and the unproblematized notion of the subject," 10 which, in the end, puts a limit on the effectiveness of colonial power and the Western subject's desire to know its Other. This limit is the source of all hybridization in nationalist discourse. According to Bhabha, this limit can then make possible the resistance of the hybrid "colonized" to the disturbed "colonizer" through the act of "mimicry." In his framework, mimicry (of the colonizer, by the colonized) is a result of this "lacking" homogenization of the colonial discourse. Mimicry,

problematizes the signs of racial and cultural priority, so that the "national" is no longer naturalizable. What emerges between mimesis and mimicry is a writing, a mode of representation, that marginalizes the monumentality of history, quite simply mocks its power to be a model, that power which supposedly makes it imitable. ${ }^{11}$

Compelling as it may be, this mode of explanation is undone by what it chooses to leave out of the equation, namely, history. That is, the historical principles of ordering, which govern practices of nationalism appear to be removed from the picture.

Bhabha's claims to describe the conditions of colonial discourse- "mimicry is...," "hybridity is..."-seem always offered as static concepts, curiously anthropomorphized so that they possess their own desire, with no reference to the historical provenance of the theoretical material from which such concepts are drawn, or to the theoretical narrative of Bhabha's own work, or to that of the cultures to which they are addressed. ${ }^{12}$

Bhabha's invention of resistance out of hybridity-resistance of nationalisms against colonial powers - is thus doomed to be a form of philosophical scholasticism, as long 
as we are not told about the political-sociological—and thus historical-connections. As this paper argues, in the case of Turkey, the re-hegemonizing power of nationalism, especially when it faces serious challenges, cannot be written off so easily merely by raising questions of ambiguity.

Obviously, it is impossible (and unnecessary) within the framework of this article to contest all objectivist or subjectivist accounts of nationalism in order to justify the sort of break that is being advocated here. ${ }^{13}$ Moreover, the divide between subjectivists and objectivists is not absolute in terms of academic practice, and usually one can find traces of both kinds of approaches in a single work. Furthermore, this article is not claiming to resolve the problems of history-writing. Despite the interest in the genesis of nationalist hegemony, and critical stance vis-à-vis official historywriting, the driving motivation of the article should be described as making sense of the contemporary situation. Nationalism in Turkey has experienced serious ups and downs. One only needs to remember the February 1997 ultimatum of the Army (famously referred as "Postmodern Coup" among the journalistic intelligentsia, resulting in the banning of the Welfare Party ${ }^{14}$ ); the absolute triumph of the nationalist right and nationalist left in the 1999 elections; the drastic changes in global politics with the terrorist attacks of 2001; and the consequent electoral victories of the AKP since 2002. A more concrete understanding of nationalism in Turkey will aid understanding the limits and possibilities and the deepening of democracy in Turkey.

With all this said, clarification of the concepts that will be employed in the article is called for. The inventory of the conceptual toolbox offered here can be listed as follows: the discussion will develop based on the understanding of politics as a field, which is historically a stage for struggles over the distribution of political and economic capital, governed by a nationalist doxa. This structure always influences the habitus of political agents and other peripheral agents, who all assume various position-takings with respect to nationalism. These position-takings are explainable through their relationship to the agents' positions and to the structure of the field of power. Below, these italicized concepts are briefly explained.

According to Bourdieu, a relational social analysis should begin first by defining the social space (whether of politics, art or education, however, the scholar is limiting his or her scope) that is going to be investigated. That construct constitutes the ground in the context of which statements concerning the dialectic between positions and dispositions, or between fields and habitus, are produced. It should be noted that Bourdieu himself is not much interested in those occasions where anomie, contingencies or irregularities govern the coordinates of a social space. Not that he ignores such instances, but rather, his research stresses how ordering principles (instead of occasions of lawlessness) and structural influences organize the social space, which is a locus of possibilities and potentialities.

Therefore, "field" as a tool concept is constructed upon the social space, which is understood as a special arena where social positions (whose history precedes that of the individuals who occupy it) and position-takings (agents' conscious or unconscious perception of their position, and their related beliefs and practices) are in a mutual relationship. A field also always operates duo-dimensionally. It is first a 
forcefield, where relationships among positions and among dispositions are constrained and hierarchized by certain external mechanisms (material or symbolic). However, it is also a battlefield, where, despite the constraints and hierarchies, agents and groups of agents are in constant struggle against each other over the control of material and symbolic resources, whose distribution governs the forces that organize the field. Consequently, in Bourdieu's words, a field may be defined

as a network, or a configuration, of objective relations between positions. These positions are objectively defined, in their existence and in the determinations they impose upon their occupants, agents or institutions, by their present and potential situation (situs) in the structure of the distribution of species of power (or capital) whose possession commands access to the specific profits that are at stake in the field, as well as by their objective relation to other positions (domination, subordination, homology, etc.). ${ }^{15}$

Given this relational definition, how should one map the space of the political field? The primary analytical importance is to reveal the integrating logic of competition between opposing viewpoints. Bourdieu tries to seek out conflict sources in politics and attempts to relate these sources to other fields, and to class and power. Yet, when he talks about politics as a field, he only has in mind party politics (and that in terms of French parliamentarism). According to Bourdieu, the field of politics has a dual structure:

On one side is the field of ideological production, a relatively autonomous universe in which, amidst competition and conflict, the instruments for thinking the social are created and where, through this process, the field of the politically thinkable, or, to put it another way, the legitimate problematic, is defined. On the other side are social agents, occupying different positions in the field of class relations and defined by a greater or lesser specific political competence-a greater or lesser capacity to recognize a political question as political and treat it as such by responding to it politically, i.e., on the basis of specifically political principles (rather than ethical ones, for example). ${ }^{16}$

Setting this overall view, he argues that the logic of this field can be explained in terms of supply and demand, where a host of political programs, issues, discourses, campaigns, views are supplied, to be consumed by a mass of citizens. For the purposes of this article, nationalism is treated as the logic behind this regime of supply. While it is reinforced by the official instruments of ideological production, in time it becomes a relatively independent logic as it begins to create its creators. ${ }^{17}$

In the political field, the rules are established so that certain agents have the authority to speak about politics, to determine what is discussable (i.e. what is politicizable, what is allowed inside politics) and what is not. In that sense, upper-class or upwardly mobile middle-class professionals dominate the field. To account for the power relations among agents within the political field (from the ordinary party 
militant to the party as propaganda machine), Bourdieu posits that the workings of the symbolic economy within the field determine who occupies which position, and to substantiate that, he offers to expand the concept of "capital."18 To explain the struggles over the definition of "what can be considered as political," according to this expansion, certain amounts of symbolic and economic resources should be accumulated, which also means that certain other people will be excluded from this accumulation and be exploited. Therefore, inside the political field, actors are distributed

(1) according to the overall volume of the political capital (and also other capitals) they possess,

(2) according to the relative weight of economic capital and political capital in their patrimony, and

(3) according to the evolution over time of the volume and structure of their capital. $^{19}$

Therefore, actors desiring to be initiated into politics should master the practical logic of the political field (i.e. being subjected to its values, hierarchies, censorship, internal fights and so on). As will be demonstrated in the following sections, in the case of Turkey, political movements and parties, while appearing to be saying radically different things all internalize this practical logic, which becomes common to all, and which is hardly questioned. Doxa (literally meaning "correct belief") is the term Bourdieu uses for the state of misrecognition or non-consciousness of the internalized rules of this game. Doxa corresponds to a set of beliefs, assumptions, categorizations, a product of objective structural conditions of the field (internal and external) and influencing individual dispositions. A crude analogy may be made to the software of a computer game, which may allow infinite play and a vast array of differently realized scenarios, but always according to an unchanging binary logic of $1 \mathrm{~s}$ and $0 \mathrm{~s}$, with which the code of the software is written. ${ }^{20}$

Bourdieu further holds that political parties are the most important players, "combative organizations specially adapted so as to engage in this sublimated form of civil war by mobilizing in an enduring way, through prescriptive predictions, the greatest possible number of agents endowed with the same vision of the social world and its future." ${ }^{21}$ In Bourdieu's understanding, parties are the agents that are more likely to influence the dynamics of the political field.

Within a political party, there exists an ethos that legitimizes the claim to represent a certain group or groups. Around this ethos, this symbolic power is shaped according to the interests of the dominant actors. These political professionals produce the choices and opinions which bring them votes and thus political power:

All political judgments, including the would-be most enlightened ones, inevitably contain an element of implicit faith, due to the very logic of political choice, which is a choice of spokesmen and representatives and also a choice of ideas, projects, programmes, plans, embodied in "personalities" 
and depending for their reality and credibility on the reality and credibility of these "personalities." 22

So, building upon this, political capital becomes a "form of symbolic capital, credit founded on credence or belief and recognition or, more precisely, on the innumerable operations of credit by which agents confer on a person (or an object) the very powers that they recognize in him (or it).",23

This mechanism for the distribution and accumulation of political capital helps understand how the aura around Mustafa Kemal Atatürk grew, and how his representation (along with the representation of the Ottomans, the Independence War, or the pre-Selchuk era) became a significant issue within the contemporary political field. Political capital can be based on fame, that is, being known and having a good reputation, available only to a few dominant agents inside the field. It can also be based on loyalty, recognition, which is not a personal capital but can only be accumulated by the political organization itself. In this form, the party gains militants, followers, new bureaucrats and most crucially, votes. This capital, through loyalty, is accumulated by structural mechanisms, party employment, task division, education and so on, and by the agents' dispositions, which "party officials or militants implement in their daily practice and in their properly political action." ${ }^{24}$ Loyalty in operation for recruitment for various legal political groups is also another means by which nationalist sentiments and dispositions are acquired.

These conscious or unconscious acquisitions of attitudes, beliefs and practices related to the political field bring us to the final tool, perhaps the sharpest and thus the most difficult to handle: Habitus is a concept that Bourdieu suggested to explain the relations between

(1) the doxa of a particular field,

(2) the field's objective conditions, internal or external,

(3) individual practices and attitudes. Briefly, habitus is "a set of dispositions, created and formulated through the conjuncture of objective structures and personal history.",25

It operates from within agents; it is embodied by agents, being the internalization of the externality of field dynamics.

In the case of the workings of the political field, habitus works as a strategy-generating principle that enables agents to cope with the requirements (as well as unforeseen surprises) of politics. Through its mediation, the agent is supplied with a system of lasting and transposable dispositions (attitudes, patterns of explanation, value judgments, etc.) which (a) integrate past experiences ("What should Atatürk mean to me?"), (b) equip the agent to decode the current ongoings of the field ("Why are Kurds troubling us?") and (c) help her customize her dispositions to what the future may bring ("What will happen if we become a member of EU?"). It is important to understand that nationalist logic is mediated differently to people occupying different positions. As a "structured" and "dynamic" structure at the same time 
(hence its sharpness as a tool), habitus may at times help external conditionings colonize the body, or at times enable the body to be ready for the unexpected.

Under the guidance of this analytical model, the discussion concerning the mapping of Turkey's political field becomes easier to navigate through.

\section{Genesis and the Structure of the Field}

In this section, the argument concerning the political field will be substantiated by focusing on a general outline of the history of modern Turkey. By first analyzing the position of the political field within the field of power and its evolution in time, and then analyzing the internal structure of the field by investigating the structure of objective relations between positions occupied by individuals and groups placed in a situation of competition for legitimacy, regularities inside the political field can be theoretically explained, and related to the sphere of economics and culture.

\section{From Domination to Hegemony}

The emergence of the social positions which facilitated the ideological production of Turkish nationalism after the second half of the nineteenth century is causally related to the economic peripheralization of the Ottoman Empire beginning earlier in that century. The emergence of Turkish nationalism is also related to the corresponding policies of modernization and institution building, beginning more aggressively with the reign of Sultan Mahmud II (1808-39) and continuing with the structural reforms in what is commonly known as the Tanzimat era (1839-76). ${ }^{26}$ As the legitimate inheritors of this first modernization period, nationalist intellectuals clashed with the imperial authority, out of which the modern Turkish political field dynamically emerged. This transformation began with the reign of Sultan Abdülhamit II (1876-1908). Undeniably a time of growing troubles for the Empire, in terms of the loss of control of land surrounding Anatolia, economic crises, threat and pressure of wars, and political mobilization against the Palace, the infamous period of istibdat (tyranny) marked the genesis of a Turkish nationalist habitus. The ideology which governed various nationalist dispositions until the July 1908 revolution by the Committee of Union and Progress (CUP) would later help consolidate the dominating logic of the political field.

At this point, it is illuminating to recall a long-standing debate among students of modern Turkish history - the well-known continuity debate between scholars identifying with Kemalism and official history-writing, and politically heterogeneous critical scholars. Basically, scholars who are critical of Kemalism ${ }^{27}$ draw attention to the continuing role of the CUP and its principles until the end of the one-party regime (1950), and also the continuity between the institutions of Ottoman modernization and Kemalist modernization. On the other hand, defenders of discontinuity (e.g. Sina $\mathrm{Akşin}^{28}$ ) stress the revolutionary aspects of Atatürk's leadership, the rupture caused by the transition to Western democratic values and the significance of the 
War of Independence. While it is true that Unionists never imagined the abolishment of the sultanate, and that Atatürk's personal ambitions about republicanism and modernization caught many political figures inside his circle of power by surprise after 1922, the Independence War period (1919-22) did not lead to a break with the already established structure of the political field. On the contrary, it led to the decisive domination of the Turkish brand of nationalism over other millets, a process that had already begun during the era of "despotism" (istibdat), and more combatively continued by the CUP after 1908 .

The nationalist opposition to the Hamidian regime, and the spread of Turkish sentiments after 1876, is basically related to two social positions, which both originated in the middle class and emerged as a result of a series of nineteenth century educational reforms. This institutional conditioning was reinforced in various ways: first, by the imperial propaganda for unity against growing nationalisms among influential groups within the Kurdish, Bulgarian, Serbian, Greek, Egyptian, Syrian and other millets; second, by the widely circulating (at least among those who had the cultural capital to follow and interpret them) texts of the Enlightenment thought. The effects of these factors became inscribed in the habitus of the new nationalist agents.

The first position was the literary intellectual, occupied by ethnic Turks primarily from Anatolia, but also at times from Azerbaijan and other Caucasian countries, who were well educated and familiar with European literary forms, who practiced one or more of these forms, and usually wrote for journals. ${ }^{29}$ Though there are dozens of influential writers, poets, novelists and journalists to consider, Şemsettin Sami $(1850-1904),{ }^{30}$ Namık Kemal (1840-88), ${ }^{31}$ Ömer Seyfettin (1884-1920), ${ }^{32}$ Tekin Alp (1883-1961), ${ }^{33}$ Yusuf Akçura (1876-1935), ${ }^{34}$ and Ziya Gökalp (1876-1924) are among the first to name. ${ }^{35}$ At this point, it is important to note that, in the period preceding CUP hegemony inside the political field, cultural production by the occupiers of this position does not completely correspond to what Anderson refers to as "imagining the nation through printed media." For one thing, the varying and competing claims concerning the definitions of "Turkishness," "being Turan," "Ottomanism," "central authority" and so on do not correspond to an imagining process of an independent nation-state. Inside the peculiar conditions the Empire was in, they should rather be interpreted as reactions to the disintegration of the Empire, and as pleas to the Sultan to hold the Ottoman realm together. This extensive cultural production did not have a concrete political program until the occupiers of the second position, junior and senior officers of the Ottoman army, decided to take matters into their own hands. Only the officers had the means to mobilize this new species of political capital to exert their influence over the central authority.

Although there is a brief period of opposition to Istanbul by a few military officers who joined the marginal Young Ottomans group before the CUP began its operations, ${ }^{36}$ there certainly was a lag between the circulation of Turkish nationalist and patriotic ideals among civilian-intellectual circles and their spread among military circles. One explanation might be that Abdülhamit was fully focused on modernizing the army. As a result, professional training colleges like Harbiye (War Academy), Bahriye (Naval Academy) and Tibbiye-yi Askeriye (Military Medical 
Academy) underwent vast changes, despite the fact that the authoritarian Sultan would not allow the process to spread beyond the circle of imperial administration. Therefore, institutions of education preparing young men for military careers were the most advanced (and, for curricular purposes, most westernized) ones, even surpassing the modern (non-religious, non-military) secondary and high schools, whose establishment had begun before the istibdat era.

Intellectual ideals were more easily distributed among junior officers, who began to read patriotic works, along with the Western classics of the Enlightenment era (including romantic-nationalist French and German literature), while arming themselves with critical political reflection on the Empire under the rule of the absolute monarch, Abdülhamit II. The Sultan, in the eyes of the officers, was one of the main reasons for ridiculing of the Empire as the "sickly man of Europe." The seeds of the CUP were sown when, in 1889, students at the Military Medical College in Gülhane founded Ittihad-ı Osmanî Cemiyeti (Society of Ottoman Unity), whose main purpose was to put an end to the rule of tyranny and to reinstate the constitution that had been arbitrarily suspended by the Sultan soon after he was enthroned. ${ }^{37}$ In five years, this organization expanded, attracting intellectual civil servants like the well-known CUP activist Ahmet Riza (1859-1930). It began publishing the journal Meşveret (Consultation) and renamed itself Ittihat ve Terakki Cemiyeti (CUP).

It is true that, until the 1908 revolution, there were a lot of opposition groups, whether nationalist or liberal, both inside and outside the military. For example, let us consider Teşebbüs-ü Şahsî ve Ademi Merkeziyet Cemiyeti (Society for Private Initiative and Decentralization), Prince Sabahattin's far less nationalist faction in the 1902 Congress of the Ottoman Liberals. The organization was also supported by progressive Armenian organizations and Jewish and Bulgarian socialist groups. ${ }^{38}$ If such an organization had mobilized the support of the officers, the structure of the political field would have been dramatically different. However, the modern Ottoman army was overwhelmingly Turkish in ethnic origin and centralist/patriotic dispositions were more likely to be in use due to military officers' social position. For example, despite these nationalist officers' personal hatred of the Sultan, they nevertheless continued loyally to perform the military tasks ordered by the Palace. Both before and after 1908, leading military figures of the CUP, ambitious young men, like Talat Paşa (1874-1921), ${ }^{39}$ Enver Paşa (18811922), ${ }^{40}$ İsmet İnönü $(1884-1973)^{41}$ and Mustafa Kemal, were all successful officers who had progressed speedily through the ranks, even though the Palace was mostly aware of their political plotting.

The process of domination by Turkish nationalism inside the political field gained new momentum through the role the CUP played in the coups of 1908 and 1913, and by the pressures of the Balkan War. It was at this point that the political power accumulated by the CUP (both in terms of military forces and civil organization) became the legitimate power in defining the enemies and friends of the Empire. This led to the banning of socialist groups, the controversial episode of the forced migration of the Armenian population, the re-establishment of a paramilitary/secret police 
organization, banning of strikes and so on. However, the doxa (of "ethnic pride," "the right of Turks to state rule," or "unity of the state") was still unstructured, because of both widespread instability throughout the Empire, and also the continued existence of an imperial dynasty that was always suspicious of CUP activities. Ottoman imperial authority remained intact until the end of World War I, and because it had undoubtedly inscribed a distinct logic of obligation and belongingness on its subjects over the preceding centuries, nationalism was not yet dominant as the mode of operation of the political field.

The partition of the Empire at the end of the war also provided the necessary conditions for the emerging dominance of nationalism. Various forces, including the CUP network, all employed a nationalist discourse of unity and solidarity. It was not, of course, a coherent and smoothly operating logic: the practice of organizing the resistance, seeking political support from local business owners and rural landlords, or persuading Kurdish tribal leaders to join the coming insurrection each required nationalist delegates and Army officers to master pragmatism above all. The strategic tools used in securing the loyalty of those recruited in resistance forces included Islam, the Ottoman understanding of cooperation between millets, demonization of the Western forces and condemnation of the Palace. The political field enclosed upon itself during this period of military mobilization and war making in Anatolia. This transformation meant that the nationalist logic eventually completely dominated the coordinates of the political sphere.

Atatürk's faction ${ }^{42}$ triumphed in the political struggle to define the legitimate means to wage the anti-occupation war, mostly as a result of its successful establishment of a new parliament in Ankara, and by doing what the CUP had not been able to, or had not dared to, attempt since 1908. This was namely, delegitimizing Istanbul's imperial authority by condemning the Palace's policies of collaboration with England, thereby effectively questioning the Sultan's patriotism. By the end of the war in 1922, the Kemalist faction had successfully monopolized all sources of the distribution of political capital. Religious groups inside the parliament were (albeit temporarily) won over through the employment of the discourse of jihad, and by the various activities of consecration of the many martyrs who had died for the patriotic cause. The peasant majority and the working poor of the cities were won over through the image of the victorious Army. Although they were an ethnically heterogeneous mass, the simple fact that a war had been won by the Ankara government against a contentious enemy was sufficient for political support. In the eyes of the people, a new Sultan was needed to heal the wounds inflicted by the war. It was this credit collected by Atatürk and his circle which allowed the Kemalists, at least initially, to silence the combined opposition within the Ankara parliament.

It was this initial monopoly over the legitimate definitions of what was proper to be politicized which allowed the nationalist alliance between the two social positions mentioned above (that of non-military intellectuals and of military officers) to replace the Empire with the Republic. To stabilize the new state of things, and to make the necessary diplomatic and commercial arrangements in order to re-establish the regime's peripheral place in the world economy, the government in Ankara 
decided to spend its political credit aggressively. At the expense of the popular support of various Sunni elements in urban and rural Turkey, and by sacrificing the support of many Kurdish tribes, Kemalist nationalist logic was now employed to govern the painfully difficult project of nation-state building.

The story of the one-party regime under the rule of Atatürk ("The Great Leader") and then of İnönü ("The National Chief") until 1950 is mostly the story of the regime spending its reserves of political capital (in other words, rapidly losing its credibility and popular support) by various autocratic means in order to consolidate state power.

As the monopoly of the Republican People's Party (CHP, Cumhuriyet Halk Partisi) ended and the multi-party era began, two enduring characteristics of the political field could be identified. The first was crystallization of the "Republican cosmology" at the core of the political capital. This was concerned with the consecration of the personality of Atatürk and of his statist principles, the will to be among the "modern civilizations," and the invention of the Turk as the super-identity (üst kimlik) which bound the citizens together. The cosmology did not condition the dispositions of different political agents in exactly the same way, but it became "taken for granted." Against this doxa, Islamist and Kurdish politicization became fundamental challenges.

The second characteristic was the enduring position of the military inside the field, whose rank-and-file officers had been imposing their agenda, using their political capital in conservative ways upon successive civilian rulers. Many officer cliques had emerged and fallen, some had re-appeared at times, positions had changed and class relations had gained new momentums. However, the military had remained an influential player. As leading scholars of Turkey argue, the structural continuities between the Empire and the Republic are largely responsible for the military's "relative autonomy" from civilian rule and accountability. ${ }^{43}$ This endurance was further strengthened until the end of the one-party regime, as the occupiers of the old position of military officers were organically linked to all sorts of civilian governmental institutions, as well as to the newly emerging (and carefully groomed) Turkish bourgeoisie.

From the perspective of the evolution of the political field, the Democratic Party's (DP, Demokrat Parti) 1950 victory was not a break. As Feroz Ahmad, in his The Making of Modern Turkey, demonstrates, although the party was a manifestation of popular opposition against the Kemalist core, it was also an instrument of the newly prospering commercial bourgeoisie and the big landowners, who found it more and more costly to negotiate with statist policies. ${ }^{44}$ Thus, the DP mobilized political capital without challenging the nationalist doxa. It sought different allies, but turned out to be as authoritarian as its political adversary in the end. The DP's failed economic program (whose turning point was the 1958 devaluation) alienated the military, which demanded more resources in order to modernize its technologies as it integrated into the new command structure of NATO.

The 1960 coup marked a moment of exception because revolutionary officers, mostly junior soldiers who despised the pro-DP old guard, acted outside the chain of command at a time when there were rival factions inside the military. The generals 
learned their lesson from this experience, and the post-1960 reforms in the military successfully ensured that this kind of autonomous action would never happen again. The military budget continually increased. The Army also undertook crucial reforms of its organizational and educational apparatuses, guaranteeing that all political interventions after 1960 would be initiated by the High Command.

To the soldiers' dismay, civilians could never march in orderly columns inside the political field. Although the ruling parties were in consensus with respect to the external dictates of the Cold War and the demands of global capital until 1980, the political field faced its first serious challenge during the 1970s. Dissident voices of political Sunni and Alevi groups, Kurdish nationalists and the legal and illegal radical left echoed through the field. The army's call for anti-communist crackdowns, the nationalist unity in its 1971 ultimatum, and the various coalition governments did not bring about harmonization of the political field. Not even the infamous "Nationalist Front" coalitions of the late 1970s helped, though they did facilitate the insertion of ultraright and Islamist cadres into state institutions, not to mention the official support given to paramilitary groups against all elements of the left.

More importantly, external pressures dictated that Turkey's long-standing nationalized developmentalism, which had governed the economic domain, had to be replaced by institutional reforms for the implementation of free market measures. However, successive governments were simply incapable of taking the bold steps. Instead, the Army, being unified and organized in itself, well-informed about what was to be done, having made the logic of the field the air it breathed, was ready to do whatever was necessary to ensure the imposition of neoliberalism. Allied with the National Intelligence Agency and the right-wing majority of the police forces, the military, operating under its nationalist logic, once again mobilized its resources to create the concrete conditions to justify a military takeover. ${ }^{45}$

The 1980 coup marked the end of the domination of the symbolic and material violence of nationalism in Turkey, and thereafter (with the 1983 return to civilian rule and the coming to power of the neoliberal Motherland Party), nationalism gradually became hegemonic. Until 1950, the political field operated like a machine; its potential for giving birth to unpredictable, out-of-control political movements was prevented by the autocratic rule of the CHP. The domination of nationalism inside the field continued after the end of the one-party era as the field opened itself, as a result of external pressures, to the conflict of various political forces. However, only the most marginal (and quickly repressed) groups dared question the very existential assumptions of the Republican cosmology and the regime's ties with capital.

On the other hand, political economic reforms after the 1980 coup facilitated drastic cultural changes. These included the integration of the rural poor into the urban middle-lower and working classes, and the emergence of an upwardly mobile white-collar class. For the bourgeois entrepreneurs, the neoliberal reforms of the late 1980s and 1990s created even better conditions to compete with Western multinationals. The field of cultural production established new connections with commodity markets, absorbing the depoliticized generation of youngsters after the coup. The Turkish-Islamic modification of higher and national education, 
oppressive measures taken against oppositional social movements, and the strengthening of mafia-like networks among military, police officers and ex-paramilitary leaders were also happening side by side with the ongoing social changes. Moreover, the mainstream parties of the central left and right obeyed similar rules in continuing the process of consecrating the Kemalist legacy, though not necessarily in ways the military would have liked.

Despite this continuity, it can be argued that the structural changes inside the economic field, until today, and also Turkey's encounter with the EU (first as a member of the Customs Union and then as an official candidate for membership), imposed changes in the political field by facilitating the emergence of new social positions. Both the existence of different positions and dispositions and the objective conditions led to a relaxation of the nationalist hold on the polity. The AKP's 2002 electoral victory and the ensuing democratic initiatives have further facilitated this process.

For one thing, the state was no longer successful in controlling the definition of the legitimate means of interpreting the Republican cosmology. The public defenses of nationalist ideology and policies more and more frequently stressed nationalism's civic virtues (like modernization, development) rather than its racist and anti-democratic shortcomings. At the same time, criticism of the logic of nationalism from the Turkish left, the Kurdish movement, and from various factions of the religious-conservative right, became more and more commonly heard. The political field was being transformed by a number of forces: first, the combination of concessions made to the advancing market forces was at play. In connection, the economic discomfort experienced by both unionized and non-unionized employees was growing. Moreover, the military and non-military elements within the state were trying to resurrect nationalist domination by campaigning against "the Islamist threat" and "the Kurdish-separatist threat." Nevertheless, despite years of AKP government, the waning of the political influence of the military and the widening of the array of political possibilities through certain democratic initiatives, the nationalist logic maintains its hegemony over the political field.

A further change in Turkey's political field relates to the dynamics of post-9/11 global politics. As the War Against Terrorism in Iraq and Afghanistan unfolded, the AKP government saw an opportunity to challenge the status of Israel in the Middle East, in terms of strengthening peace and stability. The government made moves to position itself as a better broker between Western countries and the region's Muslim populations. New democratic opportunities emerged, but without resolving or negotiating the principal challenges (that of the Kurdish movement and of political Islam) against the nationalist logic. The AKP mobilized its decisive control (since the 2007 general elections and the 2009 municipal elections) over the parliament and municipal authorities to challenge, only partially successfully, the influence of the military in governmental and policy-making affairs. With the controversial Ergenekon lawsuit, steps were taken to dismantle the dysfunctional paramilitary elements within the state, which had become entrenched during the years of war against Kurdish insurgents. ${ }^{46}$ From the perspective of the structure of the political field, it can be argued that, by 2010, new opportunities had emerged for the political 
actors inside the field to move Turkey toward a more ideal-typical liberal democracy from being an entrenched, nationalist electoral democracy. ${ }^{47}$

However, despite opportunities for deepening democracy in Turkey, the ethnocentric, authoritarian and conservative profile of the nationalist logic of the field was far from being dismantled under the AKP rule. A more complete assessment of why this is so necessitates an inquiry into two critical contemporary challenges against the structure of the field that relate to the public claims of Sunni-religious and Kurdish-ethnic identity politics.

\section{"Impostors in the Temple": Religious and Ethnic Challenges}

The opposition of orthodox Sunni groups and Kurdish distrust of the Kemalist regime during the 20 years following the 1980 coup have a deeply rooted history in the development of the Republic. While the historical details of these connections are beyond the scope of this article, it is important to note one thing related with the structure of the political field. The initial (i.e. pre-World War II) assumptions of the Kemalist logic about religious and ethnic elements within the boundary of the nation-state were, in the late 1980s and 1990s, once again mobilized by dominant political actors to decode the Kurdish insurrection and the Islamist electoral victories as threats against nationalist unity. At the beginning, the Republic had invented itself by monopolizing and controlling public representations of Islam and by radically denying Kurdish difference. The emergence of these contemporary forms of politics which undermined the operation of the nationalist logic was therefore interpreted as sacrilege. Until the 2002 elections, all governments, harmonizing their politics with the agenda of the military, carried out legal, public, illegal and parliamentary campaigns attempting to eliminate problems, thus normalizing the nationalist logic in its controlled religious, conservative and ethnocentric state.

However, the political field could not be used, as it had been in the one-party era, as an apparatus to dominate social and economic processes outside its boundaries. There were too many dents and holes in the armor. Instead, uncontrollable forms of identity politics, integrated with the changing economic conditions, emerged. Therefore, the regime's battles (and those of consenting elements inside society) against such threats had to be carried out in the form of entrenched hegemonic struggles rather than an allout war. Yet within these struggles, the strategic advantage remained in the hands of those who had mastered the nationalist logic.

\section{The Religious-Political Challenge}

Of the two challenges, the rise of the religious Welfare Party (beginning with its victory in the municipal elections of 1994) as the gravitational center of a number of heterogeneous Islamist groups was, arguably, less disturbing for the nationalist logic than the Kurdish politicization. The post-2002 integration of the AKP into the nationalist logic, as it abandoned the more outwardly Islamist forms of conservative politics, demonstrates that point. 
Most assuredly, when media discourses, the campaigns of pro-establishment civil society organizations and concrete measures taken by the state are carefully examined, the tendency was to reduce the heterogeneity of Sunni religious politics to a single, totalized enemy. However, this strategy was not credible enough in the eyes of the public, which in turn problematized the assumptions of the regime about "uncontrolled Islam." Meanwhile, the social positions occupied by the dominant figures of Welfare Party politics armed them with dispositions which led to the preaching of another nationalist version of the "civilizing project," ${ }^{48}$ one with religious implications.

After the Welfare Party was banned, its successor, the Virtue Party, abandoned the more radically fundamentalist elements of Islamist politics. Its leaders became interested in the newly emerging conservative business circles, supported by their most precious supporters from small provinces and towns, the petty entrepreneurs. These two socio-economic groups' social positions depended on the business connections they had secured in their competition with the culturally secular, more proWestern business groups, which traditionally preferred mainstream right-wing parties. The Virtue Party, not for pragmatic purposes to prevent another ban, but in order to stabilize the movement's position in the center of the political field as an establishment party willing to play the game, tried to move toward a confused mixture of social democracy and reformist Islamism. ${ }^{49}$ For example, the party's MPs, back in 2000, allied with more left-wing political groups in supporting the EU accession process, and in public criticisms of the anti-democratic activities of the state, such as its condemnation of the project to switch from prison dormitories to cells advocated by the Ministry of Justice. However, the perceived threat of the party against the regime, as well as the inner struggles within the party, prevented it becoming mainstream, and the party was banned in June 2001.

Until the banning of the Virtue Party, the organization appeared to have continued to hold a monopoly over what was politicizable for pious Sunni citizens. However, the banning decision further convinced Tayyip Erdoğan's faction that the National Outlook movement's monopoly over the political representation of Sunni identity politics was no longer sustainable without further mainstreaming conservative politics. The traditionalist faction within the National Outlook movement rejected such an integrationist incursion within the political field, sticking with their version of religious identity politics inside the newly formed Felicity Party after 2001.

Beginning with the AKP victory in the 2002 elections, it can be argued, within the analytical framework offered in this article, that the political field entered a significant but not fundamental episode of restructuring, which was still unfolding toward the end of the second term of the Erdoğan government.

On the one hand, it is notable that, as a result of the AKP policies, there was a shift, between 2002 and 2010, from the dull and insincere electoral-democratic political environment toward an embattled, largely imperfect, but achievement-oriented liberal-democratic environment. For better or worse, from a purely comparative (compared with previous post-1980 administrations) perspective, the Erdoğan 
government appeared to have distanced itself from the repressive operations of the nationalist logic of the field. This is seen in various initiatives.

Constitutional amendments reduced military autonomy and strengthened governmental oversight of the affairs of the Turkish Armed Forces. Parliament implemented EU-related harmonization packages in spheres like freedom of association, freedom of expression, minority rights. The government launched an initiative for major constitutional reform and adopted a new Civil Code and Criminal Code. Finally, there was genuine political engagement (with not-so-positive results by the end of 2010) with a de-militarized policy to reconcile Kurdish demands. All these actions supplied AKP with considerable political capital within the field, which allowed the party to accumulate enough social credibility to carry it successfully through two national elections, two municipal elections and the contentious referendum of September $2010 .{ }^{50}$

Yet, on the other hand, the electoral and democratic success of the AKP in office does not mean that the whole field has been transformed and its nationalist modus operandi has shifted toward a more liberal logic of constitutional citizenship. While the AKP policies have, intentionally or not, created opportunities inside the polity for pushing the government (especially via civil society and social movement organizations) toward deeper democratic reform, after seven years, the AKP's actual, though unintended function has been the completion of the absorption, and thus neutering, of the Islamist challenge to the hegemonic logic of Turkey's political field. ${ }^{51}$

In Turkey, there has been, historically speaking, ceaseless competition over the proper monopolization of political capital inside the field. Political entrepreneurs, whether they have secular, militarist, Atatürkist, religious, conservative, centrist, anti-communist or pan-Turkist dispositions, share, mostly unconsciously, the nationalist doxa, once they are socialized and politicized into the rules of the game (when "politics as a vocation" becomes inscribed on their habitus). Through their power struggles, as a result of which political capital is mobilized to articulate certain other interests, they compete over how to secure control (and, they hope, domination) over what can properly be politicized and represented inside the field. This explains the various clashing claims over the cultural-historical contents of the "Turkish people," over the transcendental definition of state and country, and over the delicate balance to be struck between citizens' duties and their rights and liberties.

For a period, in the 1990s, the Islamist challenge to the doxa (the glue that had been holding the political field together for a long time) had the potential to overwhelm the field, not in terms of (as is often argued) replacing the Republic with a religious theocracy, but in terms of reversing the unequal distribution of political and economic capital by mobilizing the urban and rural poor under the promise of religious solidarity and religious freedom. Well before other political actors (including the military), who were the adversaries of the National Outlook movement, the rank-and-file of the Welfare Party, increasingly frequented by upwardly mobile businessmen, had seen the risk of failing to contain the effects of their public-religious message. Therefore, AKP's emergence and political success, above all, can be explained by its skillful monopolization of the representation of religious-conservative sentiments to 
contain the risk of religiously motivated outrage against those "old" political actors who were largely perceived to have betrayed the people in the aftermath of the 1999-2002 economic (and social) crisis. ${ }^{52}$ Moreover, unlike the authoritarian attempts of the military, exemplified by the so-called February 28th Process, and the later affirmation of the military's mindset by secularist elements of the judiciary (leading to banning of two National Outlook parties), AKP's containment strategy neatly remained within the confines of electoral democracy, backed by a discourse of rights and liberties. It was thus AKP's rank-and-file who re-harmonized the operation of the nationalist logic with the changing times.

Some observers of AKP appear perplexed by the vagueness of the party's ideological profile ${ }^{53}$ or think that the party may be hiding a secret agenda for the radical Islamization of Turkey ${ }^{54}$ We believe, however, that such accounts fail to ask the proper questions. Once the positioning of the party is recognized as the agent of the political field's re-constitution of its nationalist logic, the meaning of AKP's tactically elaborate utilization of religious, ethnocentric, liberal, pro-business or multicultural discourses become clearer.

\section{The Ethnic-Political Challenge}

Unlike the case of Islamist politicization, nationalist logic could not so easily digest the political and paramilitary challenge which began in 1984 with the armed insurrection led by Kurdistan Workers Party (Partiya Karkaren Kürdistan, PKK). As Mesut Yeğen, in his book Devlet Söyleminde Kürt Sorunu [The Kurdish Problem in State Discourse], demonstrates through discourse analysis, Kurds were portrayed in different fashions in history in the discourses of the Kemalist regime. ${ }^{55}$ It was of utmost importance for the regime to come up with a new way to eliminate the "Kurdish problem." Kurds had been mere mountain Turks for a long time; an uncivilized people; a community of unruly smugglers and bandits; an offshoot tribe of noble Turkic communities, whose manners had to be Turkified for the modern nationstate. ${ }^{56}$ The emergence of the self-styled Marxist-Leninist PKK, with a radical program (at least initially) aiming to purge southern Turkey's feudal elements and establish a separate socialist state, resulted both in further oppression of all elements of Kurdish popular culture and the commonplace association of almost all Kurds with terrorism. ${ }^{57}$ In this process, the old mountain Turk became first an anarchist, and later a terrorist, traitor and enemy force.

From 1992 to the arrest of the PKK leader Abdullah Öcalan in 1999, with the administrative and legislative support of successive coalition governments, the military and the police constructed an oppressive and costly war machine inside eastern and southeastern provinces. The resurrection of ultra-nationalist paramilitaries, this time under the official title of Special Forces, the assassination operations against Kurdish journalists and Kurdish businessmen, the military's control of the supply of everyday goods in the region, the burning down of strategic villages and forced migration out of the rural areas prone to PKK activities, the strict control of the media - all these, and other questionable policies employed under the operating 
logic of the field, gave the military an opportunity to re-establish its nationalist domination over the field. ${ }^{58}$

Consider the position of the Turkish Armed Forces just before the AKP electoral victory of 2002, during a time when the Turkish economy was just recovering from crisis, and a time of perceived global insecurity in the aftermath of 9/11: with 15 years of anti-guerrilla warfare experience, operating under permanent red-alert conditions during that time in the security risk regions, and having enjoyed a substantial budget for its public and classified operations, it was a formidable player inside the field (and also within the Middle East).

However, the political field resisted the chain of command. Even before the PKK suspended its armed struggle in 1999 after Öcalan's arrest, many dissident voices had begun to be heard inside the field. The most controversial (and unexpected) of these were the public criticisms of the state's militarized strategies by the Association of Turkish Industrialists and Businessmen (TUSIAD) and the famous Turkish Union of Chambers of Commerce and Industry (TOBB) Report of 1995. ${ }^{59}$ These early initiatives called for a political-economic or developmental solution, stressing that the Kurdish Problem did not start and end with the PKK.$^{60}$ Business circles were openly skeptical about the function of ultra-nationalist myths for the resolution of the problem. They responded to the state's criticisms about the lack of business investment in the Southeast by implicitly recommending the end of the military's strong presence there and the end of the state of emergency rule. Meanwhile The People's Democratic Party (HADEP), the then representative legal political actor within Kurdish politics, mobilized a considerable amount of public support in Kurdish provinces, despite the obstacles the regime set for it. HADEP's distancing itself from PKK's nationalist-socialist and militaristic jargon also facilitated its credibility, which was based on a political capital totally outside the structure of the field. Unable to absorb the legal dimension of Kurdish politics, the regime banned three Kurdish parties (beginning with HADEP in 2003) until 2010, and the latest party, Peace and Democracy Party (BDP, Barış ve Demokrasi Partisi) faces further prosecution.

It is true that the episode that started with Öcalan's arrest and trial was a time for media-pumped nationalist hysteria in the country. However, it turned out that this "ultimate victory over terrorism," as it was declared, would give an even more challenging momentum to Kurdish politicization. The PKK had already been deemphasizing its secessionist claims since 1995 as the party's military defeat became apparent. Also, after Öcalan founded his court defense upon the issue of ethnic rights, and commanded his party to end armed struggle, the military completely lost its political control over the circulation of issues like the public debates about the atrocities of the "state of emergency" regime, or the legalization of Kurdish TV and Kurdish education.

The turn of the events with Öcalan's arrest gave new and complex twists to the challenge of Kurdish politics. The episode further coincided with Turkey's official acceptance as a candidate state for EU membership in November 1999, resulting in an important change in the political opportunity structure for leading Kurdish 
groups. Even the mainstream media somewhat reversed its ultra-nationalist discourse and opened its screens and pages to debates about why there had been so many Kurdish rebellions in Ottoman and Turkish history, what the relationship was between the Kemalist regime and Kurdish tribes, how to define "Turkishness," what the limits of ethnic right should be, and so on. Such debates on reconciling Turkish and Kurdish identity politics still continue today. At one point in 2000, Şenkal Atasagun, the then head of the National Intelligence Agency, gave a major press conference, an unheard-of practice in the institution's history, and repeated the government's positive views on the necessity to facilitate the development of Turkey's Kurdish minority and enable them to become equal citizens with the majority. However, soon after, the military published a report prepared by the Intelligence Bureau of the General Staff, announcing that PKK merely gives lip service to the whole ethnic rights debate, while still preparing for secession, and concluding that measures like Kurdish language TV should remain out of the question.

While armed violence did not end after 2002, its intensity definitely waned, as various armed factions within PKK emerged with differing political agendas. The AKP immediately recognized that, unlike its own absorption and containment of the Islamist challenge, embracing Kurdish politics within the current rules of political game would prove difficult. What happened after mid-2005, the moment the party decided to take up the challenge proactively, reinforces this article's assessment about how the political field can be restructured without dislocating the nationalist logic.

In November 2005, Erdoğan made a public statement in Diyarbakır in southeastern Turkey, admitting some of the official mistakes of the past and accepting that the Kurdish problem was the problem of his administration. This marked the beginning of a more substantial initiative to negotiate the boundaries of what can be politicized concerning the representation of Kurdish demands. Defining Turkey as an ethnic mosaic, Erdoğan emphasized the necessity of re-integration and reconciliation under the supra-national identity of Turkish citizenship. ${ }^{61}$ To this new discursive strategy for monopolizing the representation of the Kurdish question, the AKP also added the dimension of Islam as the point of suture. Turks and Kurds would, according to the party line, easily find common ground through the shared belief system. ${ }^{62}$

This initial step, without the backing (at that point) of any substantial policy initiative, failed due to the tragic events of March 2006 in Diyarbakır. Following the funerals of four PKK militants killed by the military in an armed clash, street violence broke out in the city, shops were destroyed and official building were attacked by Kurdish protestors, some of whom were children. The police responded with violence, and six citizens were killed, including two children. ${ }^{63}$ In the face of opposition accusations of being soft on terrorists, the AKP government decided to respond by reenacting imposing the Anti-Terror Law in the region. In the process, the legal and powerful contender for the political representation of Kurdish demands, DEHAP (Democratic People's Party) abolished itself before being banned by the Constitutional Court, a move which further damaged AKP's gestures toward reconciliation. On top of this development, which pushed Turkish-Kurdish relations back to the 
status quo of the pre-1999 period, it should also be recalled that the AKP failed to challenge the paramilitary establishment that surfaced with the "Şemdinli Incident" of November 2005. At that time, two military officers in civilian clothes and a former PKK member were caught near the scene of a bombing attack on a bookshop, with similar bombs and a sketch map of the area in their cars. The judicial process which would have also attempted to reveal the chain-of-command leading to the attack, did not lead to satisfactory outcomes from the perspective of democratization.

Despite what Yavuz and Özcan pessimistically observed about the AKP's policies concerning the Kurdish question, ${ }^{64}$ the AKP was not content with the way things turned out in its confrontation with the Kurdish challenge. At this point, it should be understood that the AKP had achieved a unique position inside the political field. It held hegemony over the representations of ethno-religious sentiments. It was a negotiator with the EU as the most successful, if not the only secular electoral-democratic nation with a Muslim majority population. It was contending with Israel for leadership in the Middle East. It was the manager of relations between culturally differing, if not opposing business circles. All this inevitably pitted the party against the subscribers to the pre-2002 political doxa ${ }^{65}$ making it politically impossible for the party to play by the previous rules. Consequently, the AKP rank-and-file knew that, unless they contained the Kurdish challenge without playing into the hands of the previous controllers of political capital, the result would be their undoing.

It is very likely that the AKP strategized to go through with the 2007 elections before taking any more "courageous" steps regarding the Kurdish challenge. Despite the failures and missteps of 2006, the party managed to secure southeastern Turkey, with 52 percent of the votes. While the parliamentary wing of the Kurdish movement (Democratic Society Party) did not entirely lose legitimacy at the ballot, it looked like a significant portion of the Kurdish citizens' consent could be secured through the AKP's political credibility on at least three issues which concerned them:

(1) the AKP's cautious gestures toward ethnic reconciliation within a framework of Türkiyelilik (literally, "being from Turkey," instead of "being Turkish");

(2) its local organization's campaign to convert Kurds' religiosity into political capital for the party ("we are all Muslims");

(3) its populist promises to alleviate the region's levels of unemployment and poverty. ${ }^{66}$

From the perspective of the AKP's ability to more strongly maneuver on the issue of the Kurdish problem, the 4 May 2007 meeting with General Büyükanıt, the Dolmabahçe Agreement, was critical. After this meeting, the overtly adversarial political incursions of the General Staff stopped. Although the military never gave concessions about their preference for predominantly military strategies to deal with the $\mathrm{PKK},{ }^{67}$ the generals did not make controversial public moves against political reconciliation with the Kurdish movement during the AKP's 2008-9 initiatives. 
Moreover, shortly after the July 2007 elections, the still-continuing complex investigation into the "terrorist organization" called Ergenekon was initiated, which opened up a public debate about unsanctioned military and paramilitary operations backed by the military. ${ }^{68}$ Since, like the Şemdinli Incident, many of these operations under scrutiny were part of the Armed Forces' war against PKK, many Kurds approved of the AKP's backing of the Ergenekon investigations, as well as the protests against alleged coup plots which became part of the investigations. The judicial process concerning the Ergenekon organization (which encompassed active military officers, high profile retired generals, university professors and other prestigious civilian professionals) was successfully converted into political capital by AKP, in the form of building a public face of a party which appears to have fully committed to the deepening and demilitarization of democracy in Turkey.

This volume and quality of political capital, then, beginning with 2008, was better suited for political investment into a second mobilization for absorbing the Kurdish challenge. The June 2008 and January 2009 initiatives, which greatly expanded representation of the Kurdish language in national radio and TV broadcasting, were implemented as just the first steps, and the party withstood both left-nationalist and right-nationalist attacks from the political entrepreneurs of Parliament's main opposition parties. ${ }^{69}$ In August 2009, the Ministry of Internal Affairs hosted a meeting, chaired by the Minister Beşir Atalay, titled "Resolution of the Kurdish Question: Towards a Turkish Model." Later that month, Erdoğan met with Ahmet Türk, DTP's leader, and negotiations appeared to have begun, though with no concrete "road map." There was promising talk of better educational rights, implementation of the rights to use the Kurdish language freely in any medium and signs of the government's intention to somehow try to persuade the PKK to disarm. However, this appearance of active reconciliation, with apparent recognition (for the first time) of DTP as a legitimate partner for dialogue, was not as sustainable as the AKP desired:

The AKP's policy appeared to be making progress in October [2009] when 34 people, including eight PKK militants, hiding out at Qandil Mountain and Maghmur Camp in northern Iraq surrendered to Turkish authorities at the call of imprisoned PKK leader Abdullah Ocalan. But the plan backfired when the pro-Kurdish Democratic Society Party (DTP) held welcoming rallies for the 34, triggering a great deal of outrage among ethnic Turks, many of whom accused the AKP of negotiating with terrorists. The Turkish government lost further control of the initiative when the main opposition parties, the secular People's Republic Party (CHP) and Nationalist Movement Party (MHP), seized on the issue, forcing the AKP leadership to reassess its Kurdish policies. $^{70}$

On December 11, 2009, the Constitutional Court issued its final decision on the case against DTP and banned the party for "becoming a focus through which actions against the indivisible unity of the state with its country and its people were perpetrated," or in other words, for "collaborating with terrorists." With this 
development, despite the quick re-establishment of the current BDP, there remained very little ground for continuing reconciliation, and the AKP initiative appears to have come to an abrupt end.

However, this most recent episode in the confrontation between the Kurdish challenge and the nationalist doxa should not be interpreted as a total failure from the perspective of the AKP. The party's strategy for the monopolization of the political representation of Kurdish demands appears to have two dimensions. On the one hand, the political entrepreneurs of this pragmatic-conservative habitus have given a performance of "willing, sincere, democratic agents who want to reinforce the bonds of fraternity with the Kurds." This performance in the second half of 2009 had three functions:

(1) publicly, DTP/BDP was forced to concede and at least join the performance as a "partner";

(2) the adversarial rivals, CHP and Nationalist Action Party (MHP), had to call even more radically for a return to the prior militarized state of affairs, through which AKP hoped to expose the "anti-democratic" aspirations of its competitors over the control of political capital;

(3) it was hoped the initiative would bring more legitimacy to the AKP's claims over "proper" leadership in the Middle East.

Yet on the other hand, throughout 2009, the DTP's local organization was under frequent attack, through arrests, lawsuits, police raids and so on. Such pressures made it difficult for the party to maintain its relative autonomy from the various armed factions trying to steer its policies, thus making it easier for the AKP to delegitimize the DTP's claim to represent Kurdish demands. Thus, the argument that the Constitutional Court decision to ban DTP ruined the AKP's plans is not convincing. For one thing, the decision played into the hands of the party by exposing the democracy-constraining consequences of the 1982 Constitution, which, nowadays, the party campaigns to revise. On the other hand, the banning gave ammunition to AKP's claim that it wished to reconcile, but could not accept such an illegitimate partner as the DTP, whose leaders were accused of cooperating with terrorists.

Consequently, in 2010, unlike the Islamist challenge, the Kurdish challenge remained uncontained. For the AKP, the principal outcome of this impasse is the party's inability to complete its retooling inside the field. As 2010 draws to an end, two contentious processes continue to complicate the issue: On the one hand, police operations and aggressive litigation against groups connected to BDP's local organizations in eastern and southeastern provinces continue. Many politicized Kurdish citizens, even officials from BDP-controlled municipalities, are alleged to be part of PKK's operations, arrested and jailed. The BDP continues to complain about foul play and links these operations with the government's "secret agenda" to neutralize the Kurdish movement. On the other hand, two interrelated controversial issues are being publicly debated, around which BDP is campaigning as of December 2010: 
(1) bilingualism in all spheres of public life (principally education), especially in provinces with majority or substantial Kurdish population;

(2) having autonomous regional powers, in the same high-Kurdish-population areas, implemented through a proposed "state government" structure similar to Spain or the USA. As the new elections in June 2011 approach, the ethnic-political challenge of the Kurdish issue operates through these two political processes.

Without the absorption of the Kurdish challenge, the AKP will be unable to establish a monopoly over the political capital circulating in the political field and will find it very difficult to reform the nationalist doxa. So far Prime Minister Erdoğan demonstrated an aggressive, combative leadership profile, hard to be negotiated with. Therefore, the challenge of the ethnic-political issues related to Turkish-Kurdish relations may eventually convince the AKP to revert to the pre-1999 rules of the game: unyielding nationalism armed by aggressive securitization, instead of deliberativedemocratic policies.

In Turkish political field, as in many other structured social worlds, "one needs to possess a great deal of capital to carry out a successful revolution.." ${ }^{, 11}$ For the sake of argument, let us assume that the party can sustain its current containment of the unruly elements inside the Turkish Armed Forces and institutionalize governmentcontrolled mechanisms (which must be grounded enough to survive after another party comes to power) to dismantle military autonomy. Even with that assumption, the success of the AKP's "revolution"72 will depend on the ability of the strategic craftsmen of the party to manufacture sufficient credibility to gain the loyalty of Kurdish citizens and completely marginalize the BDP. The other option, the path that would possibly deepen democratization inside the political field and break the hold of nationalism, contradicts with the hegemonic policy performance we have witnessed in the AKP so far. Finding an operational middle ground with the BDP and PKK, without attempting to repress the social bases of the movement represented by these two, would perhaps be the boldest move inside modern Turkey's political field since the declaration of the Republic. However, the current AKP leadership is signaling its will to absorb and hegemonize. That path may get the votes in June 2011, but the nationalist doxa will remain unchallenged.

\section{Conclusion: The Symbolic Power of Nationalism}

If the arguments about the structural continuity ${ }^{73}$ between imperial (Ottoman) and Republican (Kemalist) military, legislative and administrative institutions have any validity; and if, by studying the history of modern Turkey, one can discern an enduring political influence of the military, then it is not a meaningless task to try to add the usually missing political-sociological dimension. This is the relationship between different political agents' homological career trajectories and biographies and their nationalist practices and dispositions. The conditioning of habitus by the nationalist doxa is particularly obvious in the case of initiation into the front ranks of mainstream media groups, where numerous upper middle class columnists can be found, who 
have internalized the modus operandi of the symbolic power of nationalism. However, the impact of the structure of the political field also seeps through the activities of certain civil society organizations, which begin to operate as political extensions of the main players in the field, supplying various (intellectual, policymaking, journalistic, philanthropic, even paramilitary) services for the propagation of political capital.

The Turkish-nationalist set of embodied beliefs about the cosmology of the Turkish nation, the nation's religion, its language; about the greatness of the Turks and their "ethnic and religious sensitivities which should be respected"; and about the "proper cultural tastes" of the nation, etc., are "sticky," both diachronically and synchronically. On the one hand, over time, these beliefs structure behaviors and dispositions across smaller social worlds within the nation. Inside the fields of literary (and other artistic) production, religion, education, bureaucracy, etc., agents learn to operate according to the "properly national" doxa and their misrecognition about this national existence becomes natural to them. This taken-for-granted and thus unchallenged set of beliefs can then be inherited by other new initiates inside various fields. On the other hand, the operation of nationalism is synchronic. At a given time inside the social space of the nation, nationalism can operate horizontally, across large chunks of the population, invoking what Bourdieu called "the logic aggregation," which

imposes itself whenever groups are reduced to the state of aggregates, sets of juxtaposed, accumulated, agglomerated elements which, like the individuals present at a given moment in the waiting hall of a railway station, coexist partes extra partes, like grains in a heap of sand, without communication or cooperating as do the members of groups mobilized towards an action, political or otherwise. ${ }^{74}$

This is the magic, or the mystery of the formation of the general will. Once political actors secure a stable monopoly over political capital, that is, they are able, using the agglomerated (usually in the ballot box) misrecognition that they are the representatives of the national will of the Turkish people, to accumulate the trust of citizens, they can conjure up the group they claim to represent. This aggregation of infinitely diverse individuals who do not know much about each other can be declared, by their representatives, as a sacred community. This invocation through the political field has a real effect on practices, dispositions and affections, as people find a (misrecognized) sense and purpose in belonging to the category into which they are called. That category (that of the Turk, the Kurd, etc.), at the particular time and place is it is invoked, instills a logic of distinction onto the agent, separating her/him from other (not necessarily adversarial, but different) categories and binding her $/$ him to the familiar one on this side of the boundary.

Throughout the history of modern Turkish politics, there have been ceaseless struggles over the construction of this boundary; and that historical process of construction essentially corresponds to the source of the symbolic power of Turkish nationalism. In other words, this article has argued that the nationalist logic of 
aggregation, with its capacity to efface many other minor (and most often politically defined as cumbersome or troublesome) differences, has been the primary issue inside the political field. What kind of a creature is the Turk? What kind should he be? It is argued here that the struggles inside the political field determine how power is distributed across classes or other social groups in other fields inside the social space of the nation. Rather, in the Turkish case examined here, it is presented that, because of the historical thinness of the system of civic checks and balances, and the weakness of the structures of constitutional citizenship (considering the current constitution was sanctioned by a military junta), the capable representatives of social groups can tap and consolidate (economic, religious, etc.) power through the only game in town: the logic of aggregation and boundary generation, ridden with authoritarian and conservative myths. Various political parties and military factions in history have accessed this political capital by converting lots of economic, religious and cultural capital into their version of the representation of the people. The heaviest price paid for being stuck in this game of stakes has been the slow pace of deepening democracy in terms of expanding the sphere of rights and liberties.

What about the near future of the political field in Turkey? If symbolic power is defined as a real force which is "defined in and through a given relation between those who exercise power and those who submit to it, i.e., in the very structure of the field in which belief is produced and reproduced." $" 75$ Today's AKP commands a lot of this power in many parts of the polity, while enjoying an incomplete, but effective domination over the nationalist means of representation inside the political field. On the other hand, there are real opportunities for diminishing the hold of the nationalist logic over the political field. Despite the current disunity of Europe, radiating doubts for many member and candidate countries, the accession process can be transformed into a stimulus for developing a post-national citizenship inside the field, challenging the old nationalist doxa. The Kurdish politics of recognition is haunted by its own nationalist limitations, but the possibility of articulating Kurdish reintegration claims with all-embracing economic redistribution claims might again pose an alternative to nationalism and expand the sphere of freedom. Unfortunately, however, with no promising political powerhouses in sight to offer an alternative to the AKP, it seems unlikely that the field will be sown with the democratizing seeds of post-national ideals any time soon.

\section{Acknowledgements}

The authors would like to thank Prof. Ümit Cizre (Bilkent University, Turkey) for her invaluable feedback on the early versions of this article.

\section{Notes}

1. Alparslan Türkeş, Yeni Ufuklara Doğru [Towards New Horizons] (İstanbul: Kamer, 1995), pp. 80-83.

2. This is not to say that it is impossible to analytically distinguish between procedural, legal, civic, etc., aspects of belonging to a national community from ethnic, racist, "emotional," etc., aspects. However, 
objectivist, non-relational, and mostly philosophically oriented accounts tend to misrecognize the determinations of power structures and the practical interplay between, crudely speaking, "good" and "bad" aspects of nationalism. See Jürgen Habermas, "The European Nation-State: Its Achievement and Its Limitations: On the Past and Future of Sovereignty and Citizenship," Ratio Juris, Vol. 9, No. 2 (2006), pp. 125-37; Michael Ignatieff, Blood and Belonging: Journeys into the New Nationalism (London: FGS, 1980).

3. 'Tariq Ali (ed.), Masters of the Universe? Nato's Balkan Crusade (London and New York: Verso, 2000).

4. Benedict Anderson, Imagined Communities (London and New York: Verso, 1991).

5. Partha Chatterjee, Nationalist Thought and the Colonial World: A Derivative Discourse (Minneapolis, MN: University of Minnesota Press, 1986).

6. It is the authors' opinion that Chatterjee is treating a chronological order of events as if they are also following a logical order, and that he remains objectivist as long as he does not give an account of the experiences of different oppressed or oppressing groups. In the case of Turkey, for example, the secular-Kemalist modernizing approach did not "arrive" at a single point. Subscribers to that approach always negotiated the content of Kemalism's nationalist ideology as a result of internal or external conditionings. Different historical "maneuvers" emerged, were contained and then re-emerged as the regime faced different challenges.

7. Andrew Davison, Secularism and Revivalism in Turkey: A Hermeneutic Reconsideration (New Haven, CT: Yale University Press, 1998).

8. Nazan Maksudyan, Türklüğ̈̈ Ölçmek: Bilimkurgusal Antropoloji ve Türk Milliyetçiliğinin Irkçı Çehresi (İstanbul: Metis, 2005).

9. Pierre Bourdieu et al., The Weight of the World: Social Suffering in Contemporary Society (Stanford, CA: Stanford University Press, 1999), p. 613.

10. Homi Bhabha, "The Other Question," Screen, Vol. 24, No. 6 (1993), p. 25.

11. Homi Bhabha, "Of Mimicry and Man: The Ambivalence of Colonial Discourse," October, Vol. 28, No. 102 (1984), p. 128.

12. Robert Young, White Mythologies: Writing History and the West (London: Routledge, 1991), p. 140.

13. It should be noted that a more modest attempt in terms of "breaking" is made here, compared with Bourdieu's disciplinary ambitions. In any case, this article engages with the best-known scholarly works on Kemalism and Turkish nationalism. It is the authors' contention that, mostly as a result of political and/or disciplinary bias (a few of these and other works are under the spell of Orientalism), these works operate on at best ambiguous theoretical grounds. The following works can be mentioned: Feroz Ahmad, The Making of Modern Turkey (London and New York: Routledge, 1993); Niyazi Berkes, The Development of Secularism in Turkey (London and New York: Routledge, 1998); Sibel Bozdoğan and Reşat Kasaba (eds.), Rethinking Modernity and National Identity in Turkey (Seattle and London: University of Washington Press, 1997); Clement Dodd, The Crisis of Turkish Democracy (Beverley: Eothen, 1990); Çağlar Keyder, State and Class in Turkey: A Study in Capitalist Development (London and New York: Verso, 1987); Levent Köker, Modernleşme, Kemalizm ve Demokrasi [Modernization, Kemalism, and Democracy] (İstanbul: İletişim, 1990); Bernard Lewis, The Emergence of Modern Turkey (London: Oxford University Press, 1968); Hugh Poulton, Top Hat, Grey Wolf and Crescent (London: Hurst \& Company, 1997).

14. Refah Partisi in Turkish. The leading Islamist party was the leading party of the two-tiered coalition government and caused many sleepless nights among military circles at the time of the ultimatum.

15. Pierre Bourdieu and Loïc J. D. Wacquant, An Invitation to Reflexive Sociology, (London and Chicago: The University of Chicago Press, 1992), p. 97.

16. Pierre Bourdieu, Distinction: A Social Critique of the Judgment of Taste (London: Routledge and Kegan Paul, 1984), p. 399.

17. Pierre Bourdieu, Language and Symbolic Power (Cambridge: Polity Press, 1991), pp. 171-72.

18. "Capital" is understood as a "social relation" in Pierre Bourdieu, "an energy which only exists and only produces its effects in the field in which it is produced and reproduced" (1984).

19. Pierre Bourdieu, Practical Reason: On the Theory of Action (Cambridge: Polity Press, 1998), p. 15. 
20. One reason why this may be a misleading analogy is that an incurable player of computer strategy games can easily predict, after some time, the game software's working patterns and realize the limits of the software. However, inside the field, conditions of reflexivity are very different - for one thing, the more one "plays" inside the field (e.g. in terms of doing politics or being exposed to political propaganda) the likelier one becomes like a "fish in water". This is one of the basic mechanisms of how nationalism inscribes itself onto the bodies of citizens.

21. Bourdieu (1991), p. 181.

22. Bourdieu (1984), p. 424.

23. Bourdieu (1991), p. 192

24. Ibid., p. 195.

25. Cheleen Mahar, Richard Harker and Chris Wilkes, "The Basic Theoretical Position," in Richard Harker, Cheleen Mahar and Chris Wilkes (eds.), An Introduction to the Work of Pierre Bourdieu: The Practice of Theory (London: Macmillan, 1990), p. 10.

26. For political economic analyses of the nineteenth century Empire using world-system theory, see Reşat Kasaba, The Ottoman Empire and the World Economy: The Nineteenth Century (Albany, NY: SUNY Press, 1988); Huri İslamoğlu-İnan, The Ottoman Empire and the World Economy (Cambridge: Cambridge University Press, 1987); Keyder (1987); S Sevket Pamuk, The Ottoman Empire and European Capitalism, 1820-1913: Trade, Investment and Production (Cambridge and London: Cambridge University Press, 1987).

27. Levent Köker and Eric J. Zürcher present two of the most carefully weaved and most persuasive works criticizing the Kemalist establishment by pointing out similarities between the pre- and post-Republic periods. See Köker (1990); Erik J. Zürcher, The Unionist Factor: The Role of the Committee of Union and Progress in the Turkish Nationalist Movement 1905-1926 (Leiden: E. J. Brill, 1984).

28. Sina Akşin, Kısa Türkiye Tarihi (İstanbul: İş Bankası Kültür Yayınları, 2011).

29. Türk Yurdu, İ̧tihat, Местиa-ı Ebuziyya, Turan, Halka Doğru and Tanin were the best-known journals appearing after the 1870s, in which pan-Turkist, Turanist (an expansion of pan-Turkism which also lays claim to the Balkan people as well as Finnish people) and Islamist articles used to be published. A full list of these publications can be found in Jacob M. Landau, Pan-Turkism: From Irredentism to Cooperation (Bloomington and Indianapolis: Indiana University Press, 1995), pp. 29-59.

30. One of the first Turkish novelists, author of a famous dictionary (Kâmûs-i Türkî). For more details, see Yusuf Akçura, Türkçülük [Turkism] (İstanbul: Türk Kültür Yayını, 1978), pp. 109-13.

31. Famous poet, playwright and journalist. His nationalist writings criticizing the weaknesses of the imperial regime provoked the Palace's anger and he fled to Europe in 1867. He returned after being pardoned in 1870 and helped in the preparation of the 1876 constitution, but again was banished by Abdülhamit. His famous play Vatan Yahut Silistre [Fatherland or Silistria] and his influence on Mustafa Kemal made him an enduring figure, especially in the Republic's national education system. For more details, see Ömer Faruk Akün, "Namık Kemal," İslam Ansiklopedisi, Vol. 9 (1971), pp. 54-72.

32. Another enduring figure, most famous for his in short stories and novels. His scholarly book, Yarınki Turan Devleti [Tomorrow's Turan State] preached that, despite the number of different millets in Ottoman geography, the Turks had to dominate state authority, in close cooperation with Arabs, because of religious ties. Jews, Armenians, Greeks all had other places to go and live, but the Turks' only home was Anatolia. For more details, see Karpat Kemal H. Karpat, "Ömer Seyfeddin and the Transformation of Turkish Thought," Revue de Études Sud-Est Européennes, 10 (1972), pp. 677-91.

33. A Jew from Serres, later a convert to the cause of the CUP and then of Kemalism, Alp (real name Moïse Cohen) is better known among European circles for propagating a number of ideals ranging from panTurkism to Turkish nationalism during the First World War, publishing in French and German. His book Türkler Bu Muharabede Ne Kazanabilirler? [What Can the Turks Gain From This War? 1914, published in English three years later] is an ardent defense of Turkish nationalism against pan-Islamism and Ottomanism. For more details, see Landau (1995), pp. 34-35. 
34. Shoulder-to-shoulder with Gökalp, he was one of the main ideologues of CUP nationalism and later of Kemalism. He was extremely active in Caucasian and Russian political circles, trying to find support among Turkic and Muslim groups for his pan-Turkist ideals. He came to Turkey in 1908 and took important positions of teaching and research in higher education institutions in Istanbul. The main emphasis in his thought is on the leadership of Ottoman Turks and their economic interests. For more details, see Muharrem Feyzi Togay, Yusuf Akçura'nın Hayatı [The Life of Yusuf Akçura] (İstanbul: Hüsnütabiat Basımevi, 1944).

35. A student of Emile Durkheim, he was the founding father of sociology in Turkey, besides his theories of nationalism. He was always close to CUP circles, and also wrote a huge amount of poetry and journalism as well as scholarly works, the best known of which is Türkçülügü̈n Esasları [Principles of Turkism, see the 1968 English translation]. His works were very influential in the consolidation of the official nationalist ideology after the declaration of the Republic in 1923 (see Togay 1944).

36. Zürcher (1984), p. 8, dates this opposition between 1865 and 1871.

37. Ibid., p. 13

38. For a discussion of the Congress and Prince's stillborn plans for a military coup against the Sultan, see Ernest E. Ramsaur, The Young Turks: Prelude to the Revolution of 1908 (New York: Russell \& Russell, 1970), pp. 64-79.

39. One of the first and most important members of the CUP, deputy to Edirne in all CUP parliaments, Minister of Internal Affairs (1913-17) and Grand Vizier thereafter until 1918, when he fled to Germany and was killed there by an Armenian in 1921. For more details, see Hüseyin Cahit Yalçın, Talat Paşa'nın Hatıraları [Memoirs of Talat Pasha] (İstanbul: Cumhuriyet Yayınları, 1958).

40. He became the number one figure of the CUP and also of the state after the coup of 1913. His successful military campaign to rescue Edirne from the Bulgarians that year made him all-powerful. He was the mastermind behind the Ottoman war effort in the First World War, and until 1918, Mustafa Kemal's archenemy. He fled to Germany in 1918 and then to Moscow, and died in a skirmish with the Red Army in 1922. For more details, see Dankwart Rustow, "Enver Pasha," in B. Lewis, Ch. Pellat and J. Schacht (eds.) Encyclopedia of Islam (2nd Edition), Vol. 2 (Leiden: E. J. Brill, 1965), pp. 698-702.

41. The "National Chief" after Kemal's death in 1938, and his right arm until that date. Joining the CUP in 1907, he became the commander of the Western Front during the independence war. For more details, see Ömer Faruk Loğoğlu, Ismet Inonu and the Making of Modern Turkey (Ankara: İnönü Vakfi, 1997).

42. "Official history," mainly accepting Atatürk's famous literary attempt (Nutuk, A Speech, see the 1929 English translation) to justify what his clique had done during and after the independence war, diminishes the role of the CUP, while exaggerating Atatürk's "independent" political maturation. The Kemalist regime, after an attempt on Atatürk's life in 1926, used this assassination plot to annihilate the remaining elements of the CUP from the party/state. The trials, where weak and contested evidence was used against some of the defendants, led to the hanging of a number of former CUP leaders. See Mete Tuncay, T.C.'nde Tek Parti Yönetiminin Kurulması (1923-1931) [The Founding of the OneParty Regime in the Turkish Republic] (İstanbul: Cem, 1989).

43. Ahmad (1993); Çağlar Keyder, "Whither the Project of Modernity? Turkey in the 1990s," in Sibel Bozdoğan and Reşat Kasaba (eds.), Rethinking Modernity and National Identity in Turkey (Seattle and London: University of Washington Press, 1997), pp. 37-51; Erik J. Zürcher, Turkey: A Modern History (London and New York: I. B. Tauris \& Co. Publishers, 1998).

44. Ahmad (1993), pp. 102-20.

45. For a journalistic historiography of the September 1980 coup, and for a portrait of the Weltanschauung of the senior officers, see Mehmet Ali Birand, Shirts of Steel: An Anatomy of the Turkish Armed Forces (London: I. B. Tauris, 1991). For a thorough analysis of the structures put into place by the Army after the coup, see Frank Tashau, Turkey: Authority, Democracy and Development (New York: Praeger, 1984). For other insightful analyses of the episode, see Berch Berberoğlu, Turkey in Crisis: From State Capitalism to Neocolonialism (London: Zed, 1982); Betül Yarar, "1980'ler Türkiyesi'nde Yeni Sağın Yükselişi” ["The Rise of the New Right in Turkey in the 1980s"], Mürekkep, No. 11 (1999), pp. 40-63. 
46. For a thorough analysis of the AKP years in Turkey, see Ümit Cizre, Secular and Islamic Politics in Turkey: The Making of the Justice and Development Party (London and New York: Routledge, 2008); William Hale and Ergun Özbudun, Islamism, Democracy and Liberalism in Turkey: The Case of the AKP (London and New York: Routledge, 2010).

47. Andreas Schedler, "What is Democratic Consolidation?" Journal of Democracy, Vol. 9, No. 2 (1998), pp. $91-107$.

48. The founding father of this political alternative for Islamic modernization, the leader of the banned Welfare Party, Necmettin Erbakan, is also known for his campaign slogan: "If Atatürk lived today, he would vote for us." For an analysis of the elements of Welfare Party's politics which agree with Kemalism, see Menderes Çınar, "Postmodern Zamanların Kemalist Projesi," Birikim, No. 91 (1996), pp. 32-38.

49. More sound analyses of that time have pointed out the Welfare/Virtue Party's willingness to glue itself into the existing logic of the political field. Ömer Laçiner's account is exemplary of this observation, which later was confirmed by the detachment of the so-called reformists from the banned Virtue Party. The establishment and coming-to-power of AKP witnessed to that political investment of mainstreaming religious-conservative politics without challenging the core of democratic procedures. See Ömer Laçiner, “"28 Şubat' Vesilesiyle Tarih ve Toplumumuza Dair Notlar" ["Remembering 'February $28^{\text {th }}$, and Notes on Our History and Society"], Birikim, No. 131 (2000), pp. 15-21.

50. Mustafa Acar, "Towards a Synthesis of Islam and the Market Economy? The Justice and Development Party's Economic Reforms in Turkey," Economic Affairs, Vol. 29, No. 2 (2009), pp. 16-21; İhsan Dağı, "Turkey's AKP in Power," Journal of Democracy, Vol. 19, No. 3 (2008), pp. 25-30; Burhanettin Duran, “The Justice and Development Party's 'New Politics': Steering Toward Conservative Democracy, a Revised Islamic Agenda or Management of New Crises?" in Ümit Cizre (ed.), Secular and Islamic Politics in Turkey: The Making of the Justice and Development Party (London and New York: Routledge, 2008); Hakan M. Yavuz, "Introduction," in Hakan M. Yavuz (ed.), Emergence of a New Turkey: Democracy and the Ak Parti (Salt Lake City: The University of Utah Press, 2006).

51. Cihan Tuğal, Passive Revolution: Absorbing the Islamist Challenge to Capitalism (Stanford: Stanford University Press, 2009).

52. It should be remembered that this crisis was additionally marked by the human costs and socio-political repercussions of the devastating earthquake of 1999, the uncertainties concerning Kurdish-Turkish relations after the 1999 arrest of Abdullah Öcalan, and the insecurities projected from the tragedy of $9 / 11$.

53. Ali Çarkoğlu, "A New Electoral Victory for the 'Pro-Islamists' or the 'New Centre-Right'? The Justice and Development Party Phenomenon in the July 2007 Parliamentary Elections in Turkey," South European Society and Politics, Vol. 12, No. 4 (2007), pp. 501-19; Hasan Bülent Kahraman, Türk Sağl ve AKP [Turkish Right and AKP] (İstanbul: Agora, 2007); Sultan Tepe, "A Pro-Islamic Party? Promises and Limits of Turkey's Justice and Development Party," in Hakan M. Yavuz (ed.), Emergence of a New Turkey: Democracy and the Ak Parti (Salt Lake City: The University of Utah Press, 2008); Hasan Turunç, "Islamicist or Democratic? The AKP's Search for Identity in Turkish Politics," Journal of Contemporary European Studies, Vol. 15, No. 1 (2007), pp. 79-91.

54. Soner Çağaptay, "Is Turkey Still a Western Ally?" Wall Street Journal (January 27, 2009). (http:// online.wsj.com/article/s812326615668940745.html).

55. Mesut Yeğen, Devlet Söyleminde Kürt Sorunu [The Kurdish Problem in State Discourse] (İstanbul: İletişim, 1999).

56. İsmail Beşikçi, Bilim-Resmi İdeoloji, Devlet-Demokrasi ve Kürt Sorunu [Science-Official Ideology, State-Democracy and the Kurdish Problem] (İstanbul: Alan, 1990).

57. Henri J. Barkey and Graham E. Fuller, Turkey's Kurdish Question (Lanham: Rowman \& Littlefield Publishers, 1997).

58. For fair accounts of the policies for "containing" the Kurdish problem, see Michael M. Gunter, The Kurds and the Future of Turkey (New York: St. Martin's Press, 1997); Robert Olson (ed.), The Kurdish Nationalist Movement in the 1990s: Its Impact on Turkey and the Middle East (Lexington, KY: The University Press of Kentucky, 1996). 
59. Doğu Ergil, Doğu Sorunu: Teşhisler ve Tesbitler [The Eastern Problem: Prognoses and Findings] (Ankara: TOBB Yayını, 1995).

60. Doğu Ergil, the director of the sociological research behind the report and its author, was then prosecuted by a State Security Court for "spreading separatist propaganda". The case against him was soon dropped.

61. Recep Tayyip Erdoğan, "Türkiye bir Mozaiktir” [Turkey is a Mosaic], Sabah, November 23, 2005.

62. Duran (2008).

63. Human Rights Association (2006) “28 Mart 2006 Diyarbakır Olaylarına İlişkin İnceleme Raporu” [Assessment Report Concerning the Events of 28 March, 2006 in Diyarbakır], HRA web site, accessed March 12, 2010 (http://www.ihd.org.tr/index.php?option=com_content\&task=view\&id=106\&Itemid=90).

64. "The AKP government is also unlikely to propose a comprehensive plan to address the Kurdish question in the future due to the conflict between state institutions and Kurdish political actors over the very definition of the problem." M. Hakan Yavuz and Nihat Ali Özcan, "The Kurdish Question and Turkey's Justice and Development Party," Middle East Policy, Vol. 13, No. 1 (2006), p. 115.

65. Chiefly, the "left-nationalist" Republican People's Party, "right-nationalist" Nationalist Action Party and the anti-Islamist elements within the military.

66. See also, Yüksel Taşkın, "AKP's Move to 'Conquer' the Center-Right: Its Prospects and Possible Impacts on the Democratization Process," Turkish Studies, Vol. 9, No. 1 (2008), pp. 53-72.

67. Egemen Başar Bezci, "The Kurdish Question in Turkey: A Critical Juncture," Tel Aviv Notes, August 17, 2009 (http://www.tau.ac.il/dayancenter/Kurdish_question_in_Turkey.pdf).

68. Gareth Jenkins, "Between Fact and Fantasy: Turkey's Ergenekon," Silk Road Paper, Central-Asia Caucaus Institute Silk Road Studies Program (http://www.silkroadstudies.org/new/docs/ silkroadpapers/0908Ergenekon.pdf).

69. Hale and Özbudun (2010), p. 77.

70. STRATFOR, "Turkey: The Ruling Party, the Military and the Kurds," Stratfor Global Intelligence Papers, December 30, 2009.

71. Pierre Bourdieu, The Social Structures of the Economy (Cambridge: Polity Press, 2005), p. 118.

72. Henri J. Barkey and Yasemin Çongar, "Deciphering Turkey's Elections: The Making of a Revolution," World Policy Journal, Vol. 24, No. 3 (2007), pp. 63-73.

73. Ahmad (1993), pp. 1-15; Metin Heper, The State Tradition in Turkey (London: I. B. Tauris, 1985).

74. Pierre Bourdieu, "The Mystery of the Ministry: From Particular Wills to the General Will," in Loïc J. D. Wacquant (ed.), Pierre Bourdieu and Democratic Politics: The Mystery of the Ministry (Cambridge: Polity Press, 2005), p. 58.

75. Bourdieu (1991), p. 170. 
Copyright of Turkish Studies is the property of Routledge and its content may not be copied or emailed to multiple sites or posted to a listserv without the copyright holder's express written permission. However, users may print, download, or email articles for individual use. 